\title{
Advantages of Sensitive Assays for Thyrotropin in the Diagnosis of Thyroid Disorders
}

\author{
By C. Bernutz, K. Horn, A. König and C. R. Pickardt \\ Medizinische Klinik Innenstadt der Universität München
}

(Received June 11/September 16, 1985)

\begin{abstract}
Summary: Using two new immunoradiometric assays for thyrotropin, we measured thyrotropin levels in serum of patients suffering from various clinically and biochemically diagnosed thyroid disorders, and in healthy controls. A thyroliberin stimulation test was performed in all patients and controls. Thyrotropin levels were measured using a solid phase IRMA in 339 patients and a coated tube sandwich assay in 152 patients. The lower limits of detection of $0.1 \mathrm{mU} / 1$ (solid phase IRMA) and $0.02 \mathrm{mU} / 1$ (coated tube sandwich assay) as well as the specificity of these two assays were superior to those of conventional thyrotropin assays. Basal thyrotropin values were clearly different between euthyroid controls and patients non responding to thyroliberin stimulation. However, the values for these two groups overlapped those for patients showing a subnormal increase upon stimulation with thyroliberin. The thyroliberin stimulation test in patients with autonomous adenomas, together with the measurement of thyrotropin using these sensitive assays, provides additional information in the low range below $1.0 \mathrm{mU} / \mathrm{l}$, i. e. below the lower limit of detection of conventional double antibody radioimmunoassays.
\end{abstract}

\section{Vorteile von empfindlichen Assays für Thyrotropin in der Diagnostik von Schilddrüsenerkrankungen}

Zusammenfassung: Thyrotropin-Konzentrationen im Serum von Patienten mit verschiedenen Schilddrüsenerkrankungen, die klinisch und laborchemisch vollständig abgeklärt waren sowie von Schilddrüsen-gesunden Probanden wurden mit zwei neuentwickelten immunoradiometrischen Assays für Thyrotropin bestimmt. Ein Thyroliberin (TRH)-Test wurde bei allen Patienten durchgeführt, bei 339 Patienten wurde Thyrotropin mit einem solid phase IRMA bestimmt und bei 152 Patienten mit einem coated tube sandwich Assay. Die untere Nachweisgrenze mit $0,1 \mathrm{mU} / 1$ (solid phase IRMA) und mit 0,02 $\mathrm{mU} / 1$ (coated tube sandwich assay) war ebenso wie die Spezifität der beiden Assays den herkömmlichen Thyrotropin-Assays überlegen. Es gelang eine vollständige Unterscheidung zwischen euthyreoten Probanden und Patienten, die keinen Anstieg des Thyrotropin auf Thyroliberin zeigten unter alleiniger Berücksichtigung der basalen Thyrotropin-Werte. In beiden Assays gab es jedoch einen „Grenzbereich“, in dem der Anstieg des Thyrotropin nach Gabe von Thyroliberin nicht vorausgesagt werden konnte. Bei Probanden mit autonomen Adenomen erhält man mit der Durchführung eines Thyroliberin-Tests und der Messung von Thyrotropin mit diesen empfindlichen Assays eine zusätzliche Information im niedrigen Meßbereich unter $1.0 \mathrm{mU} / \mathrm{l}$, das bedeutet in einem Bereich, der unterhalb der unteren Nachweisgrenze von herkömmlichen Doppelantikörper-Radioimmunoassays liegt.

\section{Introduction}

Within the last few years thyrotropin radioimmunoassays using polyclonal antibodies have become sufficiently sensitive for the detection of thyrotropin levels lower than the normal serum range. This increase in assay senisitivity, however, involved the use of cumbersome procedures for tracer purification, and prolonged incubation periods $(1-4)$.
Recently, new assay methods for thyrotropin based on the IRMA technique and the use of monoclonal antibodies have been introduced. Major advantages of these newly developed methods are higher sensitivity and shorter incubation periods, compared with conventional double antibody radioimmunoassays. These assays permitted the separation of healthy controls and patients with overt hyperthyroidism using 
basal thyrotropin levels alone $(5-10)$. However, the diagnosis of hyperthyroidism is usually established by measuring increased thyroid hormone levels, and evaluation of thyrotropin secretion is not necessary. For the diagnosis of borderline hyperthyroidism with ambiguous peripheral thyroid hormone levels the performance of a thyroliberin stimulation test was also necessary. The new thyrotropin assays would be an advantage, if all non-responders to thyroliberin administration could be separated from euthyroid persons using basal thyrotropin levels alone. The stimulation test with thyroliberin would then no longer be required.

In the present study thyroliberin tests were performed in patients with various clinically and biochemically diagnosed thyroid disorders, and in healthy controls. Thyrotropin levels were determined using two new sensitive assays with monoclonal antibodies.

\section{Materials and Methods}

New thyrotropin assays using monoclonal antibodies

Solid phase IRMA (Serono Diagnostics): Three different monoclonal antibodies raised against thyrotropin (TSH) were used. Two antibodies labeled with ${ }^{125} \mathrm{I}$ are reportedly directed against different epitopes both on the $\alpha$ - and $\beta$-subunit of thyrotropin. A third fluorescein isothiocyanate conjugated antibody detects an epitope only present on the $\beta$-subunit of thyrotropin. Standard or serum samples are incubated with these three antibodies for 2 hours. The incubation period is terminated by adding a sheep polyclonal antifluorescein isothiocyanate antibody tagged to a magnetic solid phase. Separation of thyrotropin antibody complex and free antibodies is achieved by exposure to a magnetic field.

Coated tube sandwich assay (RIA gnost, hTSH, Behring): This assay is performed in polystyrene tubes coated with a monoclonal antibody against the $\beta$-subunit of thyrotropin. Standard or serum samples are added together with a second monoclonal antibody reacting with a determinant at the combining site of $\alpha$ - and $\beta$-subunits. This antibody is labeled with ${ }^{125} \mathrm{I}$. After incubation the supernatant is decanted, then after washing the tubes are placed into a gamma counter to determine wallbound radioactivity. This assay, now commercially available, was kindly supplied by Behring for clinical evaluation.

Incubation procedures for both assays are detailed in table 1. The coated tube sandwich assay was performed according to the producer's instructions. For easier handling we prolonged the first incubation period of the solid phase IRMA overnight; to reduce costs, only half of the original nolumes was used.

\section{Thyroliberin stimulation test}

In all patients a thyroliberin stimulation test was performed: serum levels of basal thyrotropin and thyrotropin $30 \mathrm{~min}$ after injection of $200 \mu \mathrm{g}$ thyroliberin were determined. Thyrotropin levels were measured using a solid phase IRMA from October to November 84 and using a coated tube sandwich assay in December 84 . In parallel, a conventional double antibody radioimmunoassay was used (11). This assay had a lower limit of detection of $1.0 \mathrm{mU} / 1$ and an incubation period of 48 hours.

\section{Other methods}

In addition, thyroxine $\left(T_{4}\right)$, triiodothyronine $\left(T_{3}\right)$, thyroxine binding globulin (TBG) were measured in all samples in a conventional double antibody radioimmunoassay $(12,13)$.

\section{Patients}

Diagnoses of patients included in the present study were based on clinical and biochemical parameters; in the case of autonomous adenoma diagnosis was achieved by technetium scan. The various thyroid disorders of patients studied are given in table 2. $T_{4} / \mathrm{TBG}$ ratio and total $\mathrm{T}_{3}$ were within the normal range in all patients except in those suffering from overt hyperthyroidism.

To evaluate the diagnostic validity of basal thyrotropin alone, the following groups were formed according to responsiveness to thyroliberin:

first group:

no response to thyroliberin (TSH $30 \mathrm{~min} \leqslant 0.5 \mathrm{mU} / 1$ measured with the solid phase IRMA, $\leqslant 0.1 \mathrm{mU} / \mathrm{l}$ with the coated tube sandwich assay). This group comprises patients with overt hyperthyroidism (elevated thyroid hormone levels) and patients with borderline hyperthyroidism (normal $T_{4} / T B G$ ratio and $T_{3}$ levels). Patients with borderline hyperthyroidism were suffering from autonomous adenomas, or thyrotoxicosis after beginning drug therapy, or they were under treatment with thyroid hormones.

Tab. 1. Incubation procedures of thyrotropin solid phase IRMA and coated tube sandwich assay. Modification of the solid phase IRMA is presented in parenthesis.

\begin{tabular}{|c|c|c|}
\hline & Solid phase IRMA & Coated tube sandwich assay \\
\hline Standard, mU/1 & $\begin{array}{l}0,(0.15), 0.4,1.0,5,10,30,50 \\
\text { (WHO 80/558) }\end{array}$ & $\begin{array}{l}0,0.15,0.5,1.5,5,15,50 \\
\text { (WHO 80/558) }\end{array}$ \\
\hline Standard, serum, $\mu l$ & $200(100)$ & 200 \\
\hline${ }^{125}$ I thyrotropin antibody, $\mu \mathrm{l}$ & $100(50)$ & 100 \\
\hline \multirow[t]{2}{*}{ Incubate, $\mathrm{h}$} & $2(16)$ & 2 \\
\hline & $\begin{array}{l}100 \mu l \text { antibody to fluorescein isothiocyanate } \\
-10 \mathrm{~min}\end{array}$ & \\
\hline \multirow[t]{2}{*}{ 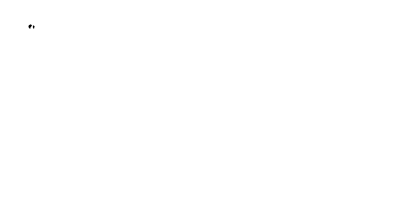 } & $\begin{array}{l}\text { magnetic separation } \\
\text { decant }\end{array}$ & $\because$ \\
\hline & $\begin{array}{l}\text { wash twice with } 500 \mathrm{ml} \text { buffer } \\
\text { decant } \\
\text { count }\end{array}$ & $\begin{array}{l}\text { wash twice with } 1 \mathrm{ml} \text { buffer } \\
\text { decant } \\
\text { count }\end{array}$ \\
\hline
\end{tabular}


second group:

subnormal response to thyroliberin (TSH $30 \mathrm{~min} \leqslant 3.0 \mathrm{mU} / 1$ for both assays). Diagnoses see table 2.

third group:

normal response to thyroliberin (TSH $30 \mathrm{~min} 3.1-20 \mathrm{mU} / 1$ for both assays).

This group comprises patients without thyroid disorders and those with endemic goiter, defined as euthyroidism in table 2.

Tab. 2. Numbers of patients with different thyroid disorders according to thyrotropin response to thyroliberin administration.

(1) no response, (2) subnormal response, (3) normal response.

\begin{tabular}{|c|c|c|c|}
\hline & & $\begin{array}{l}\text { Solid } \\
\text { phase } \\
\text { IRMA }\end{array}$ & $\begin{array}{l}\text { Coated } \\
\text { tube } \\
\text { sand- } \\
\text { wich } \\
\text { assay }\end{array}$ \\
\hline Euthyroidism & (3) & -215 & 79 \\
\hline $\begin{array}{l}\text { Thyroid hormone } \\
\text { treatment of } \\
\text { endemic goiter } \\
\text { thyroid carcinomas }\end{array}$ & 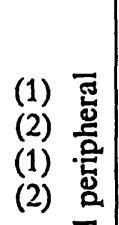 & 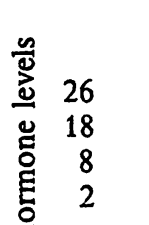 & $\begin{array}{r}7 \\
20 \\
6 \\
4\end{array}$ \\
\hline Autonomous adenomas & $\begin{array}{ll}\text { (1) } & \text { E్ } \\
\text { (2) } & \end{array}$ & $\begin{array}{rr}E & 14 \\
& 5\end{array}$ & $\begin{array}{l}7 \\
5\end{array}$ \\
\hline Hyperthyroidism (treated) & $\begin{array}{l}(1) \\
(2)\end{array}$ & $\begin{array}{r}12 \\
7\end{array}$ & $\begin{array}{l}2 \\
7\end{array}$ \\
\hline Hyperthyroidism (non treated) & (1) & 32 & 15 \\
\hline Total & & 339 & 152 \\
\hline
\end{tabular}

\section{Results}

\section{Assay characteristics}

The lower limits of detection, based on results for the zero standard samples, plus $3 \mathrm{SD}$, were $0.1 \mathrm{mU} / 1$ (solid phase IRMA) and $0.02 \mathrm{mU} / 1$ (coated tube sandwich assay). The intra- and interassay coefficient of variation for both assays are listed in table 3 .

\section{Cross reactivity}

In order to evaluate the cross reactivity of the coated tube sandwich assay with chorion gonadotropin, sera from 66 pregnant women without thyroid disorders were investigated. No difference in thyrotropin levels was seen between women in the first trimenon and those in the second or third trimenon. The mean values of thyrotropin were $1.07 \pm 1.03 \mathrm{mU} / \mathrm{l}$ $(\overline{\mathrm{x}} \pm \mathrm{SD}, \mathrm{n}=12)$ within the first trimenon, $1.06 \pm$ $0.7 \mathrm{mU} / \mathrm{l}(\overline{\mathrm{x}} \pm \mathrm{SD}, \mathrm{n}=31)$ in the second trimenon and $1.19 \pm 0.6 \mathrm{mU} / \mathrm{l}(\overline{\mathrm{x}} \pm \mathrm{SD}, \mathrm{n}=23)$ in the third trimenon.

\section{Validity of the assays}

In figure 1 basal thyrotropin levels measured with the coated tube sandwich assay are plotted versus the $30 \mathrm{~min}$ values after thyroliberin administration; the resulting correlation coefficient is $0.79(n=115)$. Non-responders to thyroliberin were excluded from

Tab. 3. Assay characteristics of solid phase IRMA and coated tube sandwich assay.

\begin{tabular}{lll}
\hline & Solid phase IRMA & Coated tube sandwich assay \\
\hline Lower limit of detection, $\mathrm{mU} / 1$ & 0.1 & 0.02 \\
Intraassay variation coefficient, $\mathrm{n}=10$ & $34.5 \%$ (thyrotropin $\leqslant 0.1)$ & $23 \%($ thyrotropin $=0.35)$ \\
& $12.5 \%$ (thyrotropin $=0.27)$ & $5.9 \%($ thyrotropin $=0.79)$ \\
& $5.3 \%$ (thyrotropin $=0.73)$ & $1.9 \%$ (thyrotropin $=2.11)$ \\
Interassay variation coefficient, $\mathrm{n}=10$ & $5.8 \%$ (thyrotropin $=1.89)$ & $3.7 \%$ (thyrotropin $=3.96)$ \\
\hline
\end{tabular}

Tab. 4. Mean and range of thyrotropin concentration in sera of normal, subnormal and non responding patients.

\begin{tabular}{lll}
\hline & $\begin{array}{l}\text { Solid phase } \\
\text { IRMA }\end{array}$ & $\begin{array}{l}\text { Coated tube } \\
\text { sandwich } \\
\text { assay }\end{array}$ \\
\hline $\begin{array}{l}\text { Euthyroidism } \\
\text { mean; mU/1 } \\
\text { range, mU/l }\end{array}$ & $\begin{array}{l}1.18(\mathrm{n}=215) \\
0.4-2.5\end{array}$ & $\begin{array}{l}1.14(\mathrm{n}=79) \\
0.3-2.3\end{array}$ \\
$\begin{array}{l}\text { Subnormal responders } \\
\text { mean, mU/1 } \\
\text { range, mU/1 }\end{array}$ & $0.38(\mathrm{n}=32)$ & $0.22(\mathrm{n}=36)$ \\
$\begin{array}{l}\text { Hyperthyroidism } \\
\text { range, mU/1 }\end{array}$ & $0.2-0.6$ & $0.03-0.9$ \\
\hline
\end{tabular}

this calculation. The correlation coefficient from 247 thyroliberin tests with the solid phase IRMA was 0.71 (data not shown).

Figure 2 (solid phase IRMA) and figure 3 (coated tube sandwich assay) show basal thyrotropin values grouped according to the thyrotropin response to thyroliberin without consideration of thyroid disorders. Patients were divided into those with normal and elevated thyroid hormone levels or according to their thyrotropin response after thyroliberin respectively (diagnoses see tab. 2). Mean values and ranges are listed in table 4. 


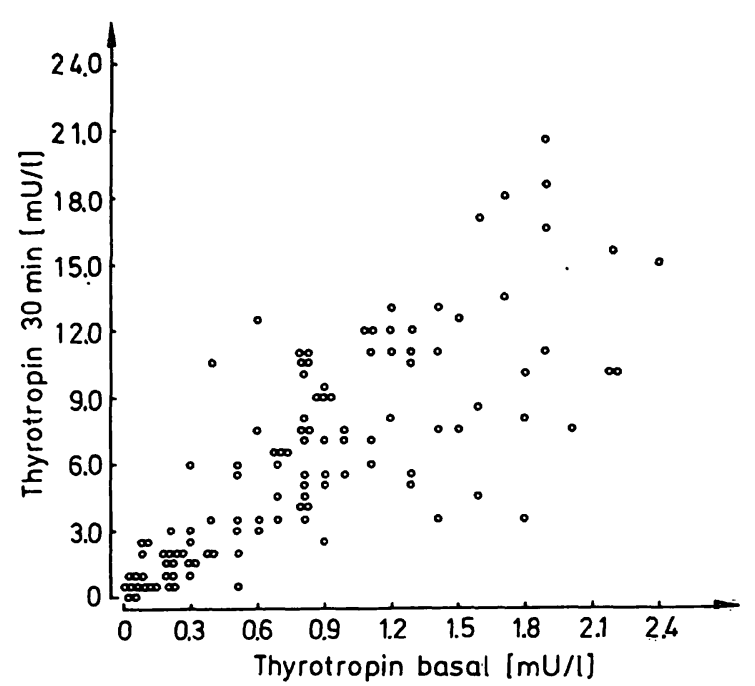

Fig. 1. Solid phase IRMA. Concentrations of basal thyrotropin measured in (left to right) patients unresponsive to thyroliberin stimulation and in those with subnormal and normal responsiveness.

- TSH 30 min $\leqq 0.5 \mathrm{mU} / 1, \mathrm{~T}_{4} / \mathrm{TBG}$ ratio and $\mathrm{T}_{3}$ elevated

c TSH $30 \mathrm{~min} \leqq 0.5 \mathrm{mU} / 1, \mathrm{~T}_{4} / \mathrm{TBG}$ ratio and $\mathrm{T}_{3}$ normal

$\triangle \mathrm{TSH} 30 \mathrm{~min} 0.6-1.0 \mathrm{mU} / \mathrm{l}$

$\triangle$ TSH $30 \mathrm{~min} 1.1-2.0 \mathrm{mU} / \mathrm{l}$

口 TSH $30 \mathrm{~min} 2.1-3.0 \mathrm{mU} / 1$

○ TSH $30 \mathrm{~min} \geqq 3.1 \mathrm{mU} / 1$

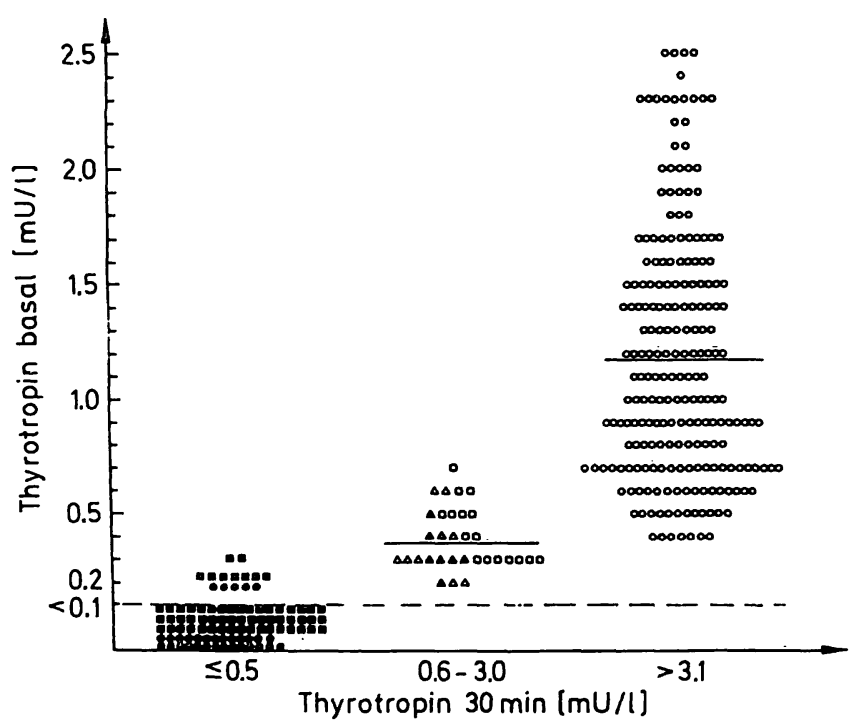

Fig. 2. Coated tube sandwich assay. Text see figure 1.

- TSH $30 \mathrm{~min} \leqq 0.1 \mathrm{mU} / 1, \mathrm{~T}_{4} / \mathrm{TBG}$ ratio and $\mathrm{T}_{3}$ elevated

- TSH $30 \mathrm{~min} \leqq 0.1 \mathrm{mU} / 1, \mathrm{~T}_{4} / \mathrm{TBG}$ ratio and $\mathrm{T}_{3}$ normal

$\Delta \mathrm{TSH} 30 \mathrm{~min} 0.2-1.0 \mathrm{mU} / \mathrm{l}$

$\triangle \mathrm{TSH} 30 \mathrm{~min} 1.1-2.0 \mathrm{mU} / \mathrm{l}$

口 TSH $30 \mathrm{~min} 2.1-3.0 \mathrm{mU} / 1$

○ $\mathrm{TSH} 30 \mathrm{~min}>3.1 \mathrm{mU} / \mathrm{l}$

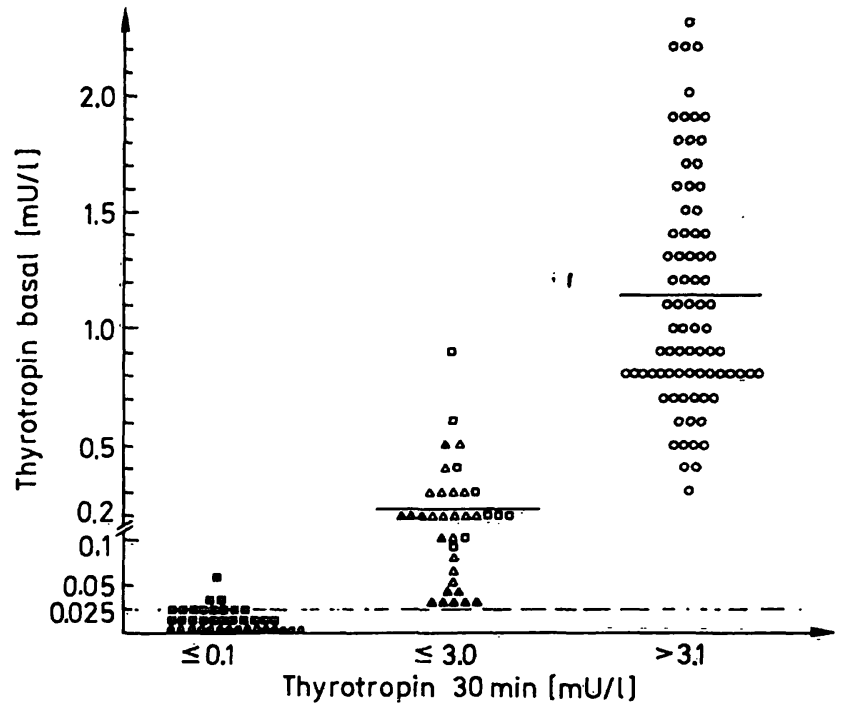

Fig. 3. Coated tube sandwich assay. Comparison of basal thyrotropin values with those after stimulation with thyroliberin.

Solid phase IRMA (fig. 2)

Basal thyrotropin levels alone showed a clear discrimination between euthyroid patients and those non responding to thyroliberin. Patients with basal thyrotropin values below the lower limit of detection did not respond to thyroliberin $(n=78)$. In the group of non-responders 32 patients were suffering from overt hyperthyroidism, but 60 patients had normal peripheral thyroid hormone leyels (borderline hyperthyroidism). The thyrotropin response to thyroliberin could not be predicted in patients with basal thyrotropin levels ranging from 0.2 to $0.7 \mathrm{mU} / 1$. Thus, patients with thyrotropin-levels of 0.2 and $0.3 \mathrm{mU} / 1$ showed no increase $(n=14)$ or a subnormal response $(n=$ 17) to thyroliberin. Patients with thyrotropin levels from 0.4 up to $0.7 \mathrm{mU} / 1$ showed a subnormal increase $(n=15)$, but more frequently a normal increase upon stimulation with thyroliberin $(\mathrm{n} \doteq 59)$.

\section{Coated tube sandwich assay (fig. 3)}

Again, the basal thyrotropin levèls alone discriminated between euthyroid patients and non-responders to thyroliberin. Serum thyrotropin levels of 34 of 37 patients non responding to thyroliberin were below the lower limit of detection of $0.02 \mathrm{mU} / \mathrm{l}$; this group comprises all hyperthyroid patients $(n=15)$. The thyrotropin response to thyroliberin could not be 
predicted in patients with basal thyrotropin levels ranging from 0.03 to $0.9 \mathrm{mU} / \mathrm{l}$. Two of 7 patients with basal values of $0.03 \mathrm{mU} / 1$ showed no response, and 5 could be stimulated up to $1.0 \mathrm{mU} / \mathrm{l}$. Eleven patients with thyrotropin levels from 0.3 to $0.9 \mathrm{mU} / 1$ showed a subnormal increase, but again more frequently a normal increase was seen $(n=38)$. The individual thyroliberin test of patients with thyrotropin levels below $0.06 \mathrm{mU} / 1$ are shown in figure 4 .

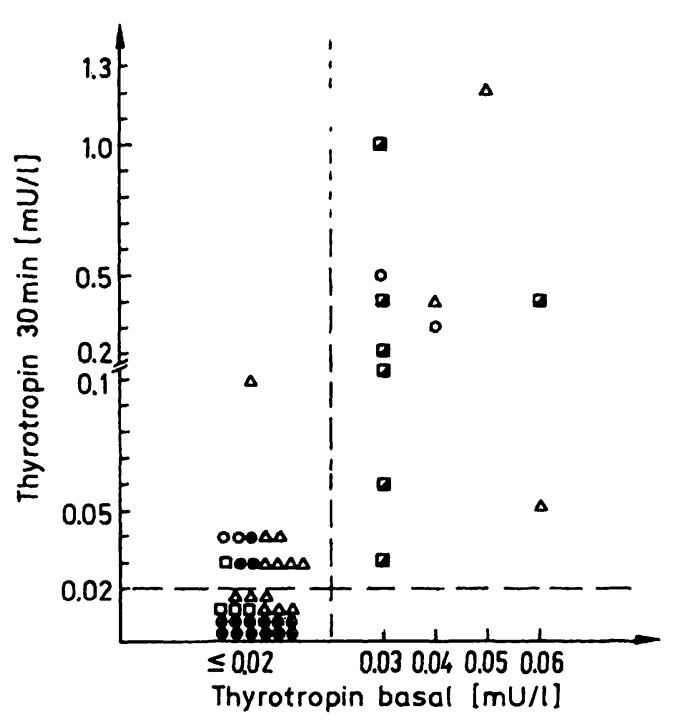

Fig. 4. Coated tube sandwich assay. Comparison of basal thyrotropin values in the range of $\leqq 0.02$ and $0.06 \mathrm{mU} / 1$ with those after stimulation with thyroliberin.

Basal and thyrotropin $30 \mathrm{~min}$ are below the lower limit of detection measured with a conventional radioimmunoassay.

- hyperthyroidism, $T_{4} / T B G$ ratio and $T_{3}$ elevated

an autonomous adenoma, normal $\mathrm{T}_{4} / \mathrm{TBG}$ ratio and $\mathrm{T}_{3}$ levels

- thyrotoxicosis, after beginning drug therapy, normal thyroid hormone levels

$\Delta \quad$ thyroid hormone therapy because of endemic goiter or after removal of the thyroid gland.

Basal thyrotropin values are plotted versus the $30 \mathrm{~min}$ value after thyroliberin administration and measured with the coated tube sandwich assay. All hyperthyroid patients are below $0.02 \mathrm{mU} / \mathrm{l}(\mathrm{n}=15)$. All other patients, i. e. those with normal peripheral thyroid hormone levels are below and above $0.02 \mathrm{mU} / \mathrm{l}$ as expected. These patients were suffering from the following thyroid disorders: endemic goiter during thyroid hormone therapy, thyroid carcinoma after removal of the thyroid gland during thyroid drug therapy and thyrotoxicosis after beginning drug therapy.
Euthyroid autonomous adenomas were detected in Tc-scan. Patients with basal thyrotropin values below $0.02 \mathrm{mU} / 1$ and no increase in thyrotropin after thyroliberin showed no paranodular uptake of nuclide $(n=4)$. In those patients with basal thyrotropin in the range of 0.03 and $0.06 \mathrm{mU} / 1$ and a subnormal increase in thyrotropin after thyroliberin administration, the nuclide was found not only in an adenoma, but also in paranodular thyroid tissue.

\section{Discussion}

In the present study we have demonstrated that a basal thyrotropin value, when determined in highly sensitive assays provides information on thyroid function almost equivalent to that gained from measurement of basal thyrotropin and thyrotropin $30 \mathrm{~min}$ after injection of thyroliberin. This is shown in figure 1 where the correlation coefficient between basal and $30 \mathrm{~min}$ thyrotropin is 0.79 .

Moreover, work, cost and time can be saved in laboratories, out patient clinics and wards by using only basal thyrotropin levels for evaluating thyroid function. Furthermore, the well-known, but usually harmless side effects of thyroliberin injection are avoided.

Both assay systems used in our study employ monoclonal antibodies against the $\beta$-subunit of thyrotropin. The inherent advantages of the monoclonal antibody approach are high specificity and sensitivity, compared with conventional double antibody radioimmunoassays. Cross reactivity with human choriongonadotropin and gonadotropins, already excluded theoretically by the design of assay, was not observed when thyrotropin levels were assessed during the course of pregnancy in 66 women.

The use of the IRMA technique allows short incubation periods and provides a high. sensitivity. Even with extremely prolonged incubation periods and sophisticated purification of tracer $(1-4)$, matrix effects prevent the achievment of an equivalent performance by conventional assays. Especially, when measuring low levels of thyrotropin, the new assays displayed a high precision. In contrast, conventional assays show variation coefficients up to $80 \%$ for low thyrotropin values (14). Both the solid phase IRMA and the coated tube sandwich assay yielded similar values for the intraassay variation coefficient, which was 5 to $6 \%$ with a serum of $0.7 \mathrm{mU} / 1$. The interassay 
variation coefficients were also comparable with values of $3.7 \%$ and $5.8 \%$ with sera of 3.9 and $1.9 \mathrm{mU} / \mathrm{l}$ respectively. Assay handling is more convenient for the coated tube assay as only one pipetting step is required and separation is easier.

The validity of both assays is similar in spite of the limit of detection of $0.02 \mathrm{mU} / 1$ for the coated tube sandwich assay compared with $0.1 \mathrm{mU} / 1$ for the solid phase IRMA. Both assays allow a clearcut discrimination of overt and borderline hyperthyroid patients and euthyroid controls. Normal ranges for both assays were similar with 0.4 to $2.5 \mathrm{mU} / 1$ for the solid phase IRMA and with 0.3 to $2.3 \mathrm{mU} / \mathrm{l}$ for the coated tube sandwich assay.

An additional advantage of a sensitive thyrotropin assay is shown in figure 4 . Basal and 30 min values were measured with the coated tube sandwich assay. The highest $30 \mathrm{~min}$ value was $1.0 \mathrm{mU} / 1$. All these thyrotropin values were below the lower limit of detection when measured with a conventional double antibody radioimmunoassay. With the coated tube sandwich assay basal thyrotropin values of all hyperthyroid patients were below the lower limit of detection of $0.02 \mathrm{mU} / 1$. However, all other patients with various thyroid disorders during drug therapy were also either below $0.02 \mathrm{mU} / 1$ or within the range of 0.03 to $0.06 \mathrm{mU} / \mathrm{l}$. This is not surprising because one would expect different degrees of thyrotropin suppression depending on the duration of the thyrotoxicosis and drug therapy. In one patient treated with thyroid hormones after removal of the thyroid gland because of carcinoma the basal thyrotropin

\section{References}

1. Spencer, C. A. \& Nicoloff, J. T. (1980) Clin. Chim. Acta $108,415-424$.

2. Pekary, A. E., Hershmann, A. F. \& Parlow, A. F. (1975) J. Clin. Endocrinol. Metab. 41, 676-685.

3. Seidel, Ch. \& Correns, H.-J. (1983) Nucl. Compact 14, 10-16.

4. Seidel, Ch., Ziegelitz, D., Weber, A., Dittmer, Th., Gerl, H., Knappe, G. \& Correns, H.-J. (1982) Endokrinologie $80,181-193$.

5. Keith, R. \& Watson, A.C. (1984) Clin. Chem. 30, $502-503$.

6. Seth, J., Kellet, H. A., Caldwell, G., Sweeting, V. M., Beckett, G. J., Gow, S. M. \& Toft, A. D. (1984) Br. Med. J. 289, $1334-1336$

7. John, R. \& Jones, M. K. (1984) Clin. Chem. 30, 1396-1398. level was $0.06 \mathrm{mU} / 1$ and showed no response after thyroliberin administration. For this exception no explanation yet is available.

The performance of a thyroliberin stimulation test in patients with autonomous adenomas may provide additional information on thyroid function. In 4 patients with basal thyrotropin values of $0.02 \mathrm{mU} / 1$, nuclide was only seen in the area of an adenoma in the scan, although peripheral thyroid hormone levels were in the normal range. In the other patients with autonomous adenomas and basal thyrotropin values in the range of 0.03 to $0.06 \mathrm{mU} / 1(n=7)$ nuclide was seen not only in the adenoma, but also in the paranodular thyroid tissue. We presume that the difference in thyrotropin secretion is responsible for the paranodular nuclide uptake. Further clinical studies are needed to clarify whether the application of thyroid hormones leads to a total suppression of thyrotropin and consequently to a decrease of paranodular nuclide uptake.

We conclude that both assays provide results enabling a clearcut discrimination of euthyroid controls and of all non-responders to thyroliberin administration (overt and borderline hyperthyroidism) using basal thyrotropin levels alone. There was an overlap of these two groups with patients showing a subnormal increase upon stimulation with thyroliberin. In patients with autonomous adenomas the performance of a thyroliberin stimulation test provide additional information in the low range below $1.0 \mathrm{mU} / \mathrm{l}$, i. e. below the lower limit of detection of conventional double antibody radioimmunoassays.

8. Kerr, D. J. \& Alexander, W. D. (1984) Lancet I, $1161-1162$.

9. Cobb, W. E., Lamberton, R. P. \& Jackson, J. M. D. (1984) Clin. Chem. 30, 1558-1560.

10. Bernutz, C., Kewenig, M., Horn, K. \& Pickardt, C. R. (1985) Clin. Chem. 31, 298-292.

11. Erhardt, F., Marschner, J., Pickardt, C. R. \& Scriba, P. C. (1973) J. Clin. Chem. Chin. Biochem. 11, 381-387.

12. Horn, K., Kubiczek, Th., Pickardt, C. R. \& Scriba, P. C. (1977) Klin. Wochenschr. 55, $881-894$.

13. Gärtner, R., Kewenig, M., Horn, K. \& Scriba, P. C. (1980) J. Clin. Chim. Clin. Biochem. 18, 571-577.

14. Marschner, J., Wood, W. G. \& Van Thiel, D. (1983) J. Clin. Chem. Clin. Biochem. 21, 301-311.

Dr. Cornelia Bernutz
Medizinische Klinik
der Universität
Ziemssenstraße 1
D-8000 München 2 